\title{
IN VITRO AND IN VIVO EVALUATIONS OF BMY-28100, A NEW ORAL CEPHALOSPORIN
}

\author{
Kozo Tomatsu, Shigeyuki Ando, Shinin Masuyoshi, \\ Shoichiro Kondo, Minoru Hirano, Takeo Miyaki \\ and Hiroshi KaWAGUCHI \\ Bristol-Myers Research Institute, Ltd., Tokyo Research Center, \\ 2-9-3 Shimo-meguro, Meguro-ku, Tokyo 153, Japan
}

(Received for publication January 5, 1987)

\begin{abstract}
A new semisynthetic oral cephalosporin, BMY-28100, was evaluated for in vitro and in vivo antibacterial activities in comparison with cefaclor and cephalexin. BMY-28100 showed in vitro activity 3- and 10-fold more potent than that of cefaclor against Staphylococcus aureus and Streptococcus pneumoniae, respectively. BMY-28100 was slightly better than cefaclor and about 4 times more active than cephalexin against Haemophilus influenzae and Neisseria gonorrhoeae. Escherichia coli, Klebsiella pneumoniae and Proteus mirabilis were comparably susceptible to BMY-28100 and cefaclor. The bactericidal activity of BMY-28100 against $S$. aureus, $E$. coli and $P$. mirabilis was equal to or twice as high as MIC value, which was similar to that of cefaclor. The stability of BMY-28100 against penicillinases was nearly comparable to that of cefaclor, whereas cefaclor was somewhat unstable to cephalosporinases. BMY-28100 was about twice as active as cefaclor against three Gram-positive bacterial infections. BMY-28100 was also more potent against infections of $H$. influenzae and $P$. mirabilis, but slightly less active against $E$. coli Juhl than cefaclor. Blood level parameters of BMY-28100 were significantly superior to those of cefaclor and slightly better than cephalexin in mice and rats. The urinary recovery of BMY-28100 was somewhat higher and comparable to that of cefaclor and cephalexin, respectively. BMY-28100 was more stable than cefaclor in human and calf sera at $37^{\circ} \mathrm{C}$.
\end{abstract}

BMY-28100 (Fig. 1), 7-[ $R$ - $\alpha$-amino- $\alpha$-(4-hydroxyphenyl)acetamido]-3-[(Z)-1-propenyl]ceph-3-em4-carboxylic acid, is a new oral cephalosporin which was synthesized in Bristol-Myers Research Institute, Ltd., Tokyo ${ }^{1)}$. In preliminary comparison, the compound has been found effective against a variety of Gram-positive and Gram-negative organisms in vitro and in vivo after oral administration ${ }^{22}$. These studies have been expanded, and in this report BMY-28100 has been evaluated with respect to its in vitro

Fig. 1. Chemical structure of cephalosporins.<smiles>CC(C)C(C)C1=C(C(=O)O)N2C(=O)C(NC(=O)c3ccc(O)cc3)C2SC1</smiles>

BMY -28100<smiles>NC(C(=O)NC1C(=O)N2C(C(=O)O)=C(Cl)CSC12)c1ccccc1</smiles>

Cefaclor $(\mathrm{CCL})$<smiles>CC1=C(C(=O)O)N2C(=O)C(NC(=O)c3ccccc3)C2SC1</smiles>

Cephalexin (CEX) 
antibacterial activity, stability against $\beta$-lactamases and in the serum, pharmacokinetics in rodents and in vivo efficacy in bacterial infections in mice. BMY-28100 was compared with cefaclor and cephalexin.

\section{Materials and Methods}

\section{Cephalosporins}

BMY-28100 was prepared at Bristol-Myers Research Institute, Ltd., Tokyo. Cefaclor (ShionogiLilly) and cephalexin (Shionogi-Lilly) were obtained from commercial sources.

\section{Bacteria}

The test organisms, 56 strains of Gram-positive and 81 strains of Gram-negative bacteria were clinical isolates and standard strains of our laboratory. The $\beta$-lactamase-producing strains of bacteria were supplied by Dr. S. MitsuHashi of Gunma University, Dr. T. SAwal of Chiba University and by the Microbiological Research Department of Bristol-Myers Company.

Determination of Minimum Inhibitory Concentrations (MICs)

MICs were determined on solid medium by the standard 2-fold agar dilution method ${ }^{3)}$. MuellerHinton agar (Difco) was used in these assay except for fastidious bacteria which were tested by gonococcus agar (Eiken). Overnight broth cultures served as the source of inoculum. A volume of approximately $0.003 \mathrm{ml}$ of the diluted culture containing $10^{6} \mathrm{cells} / \mathrm{ml}$ was applied to the surface of the antibioticcontaining agar plates with a multi-inoculator. After incubation at $37^{\circ} \mathrm{C}$ for 18 hours, plates were examined for colony development, and the MIC, the lowest concentration of antibiotic causing no visible growth, was recorded.

\section{Bactericidal Activity}

The bactericidal activity of the cephalosporins was determined by exposing various organisms to a 2-fold series of antibiotic concentrations in Mueller-Hinton broth. Initial cell concentrations were adjusted to about $10^{5} \mathrm{cells} / \mathrm{ml}$. Quantitative killing curve studies were performed by incubating the broths at $37^{\circ} \mathrm{C}$ for 24 hours. Samples were removed at $1,2,4,6,8$ and 24 hours and the number of viable bacteria was determined. The lowest concentration of antibiotics that reduced the initial cell count by $99.9 \%$ after overnight incubation was designated as the minimum bactericidal concentration (MBC).

\section{Stability to $\beta$-Lactamases}

The $\beta$-lactamases used in this study were purified by the method described previously ${ }^{4}$. Stability to various $\beta$-lactamases was determined by spectrophotometric assay by measuring the absorbance at the absorption maximum of each compound as previously reported $\left.{ }^{5}, 8\right)$. Difference in extinction between BMY-28100 and corresponding hydrolyzed one was measured at $282 \mathrm{~nm}$.

\section{Protective Effect}

Organisms were cultured overnight at $37^{\circ} \mathrm{C}$ in heart infusion broth and suspended in $5 \%$ hog mucin (American Laboratory, Omaha, Neb., U.S.A.). Male $d d \mathrm{Y}$-mice weighing 19 to $24 \mathrm{~g}$ were infected intraperitoneally with about 100 times of the median lethal dose of the pathogen. Five mice at each dose level were individually given an antibiotic solution orally just before the bacterial challenge. The $50 \%$ protective dose $\left(\mathrm{PD}_{50}, \mathrm{mg} / \mathrm{kg}\right)$ was calculated by the method of LITCHFIELD and WILCoxON ${ }^{7}$, from survival rate recorded on 7 days after the bacterial infection.

\section{Blood Level and Urinary Recovery in Mice and Rats}

Male $d d \mathrm{Y}$-mice, weighing 18 to $22 \mathrm{~g}$, and male Wister-rats, 150 to $200 \mathrm{~g}$, were given antibiotic solution by oral administration. The antibiotic activity of blood samples collected from the orbital sinus was assayed by the paper disc - agar diffusion method. Micrococcus luteus PCI-1001 was used for assay organism. A group of five male $d d \mathrm{Y}$-mice or male Wister-rats given antibiotic solution orally, was kept in a metabolic cage and urine specimens were collected during 24 hours after administration. Antibiotic activity of urine samples was assayed by the same method in blood level experiment. 


\section{Stability in Serum}

Stability in human and calf sera was determined at $37^{\circ} \mathrm{C}$. The initial concentration was $100 \mu \mathrm{g} / \mathrm{ml}$ in $90 \%$ serum and $10 \% \mathrm{pH} 7.0$ phosphate buffer solution and residual antibiotic activity was determined by the paper disc-agar diffusion assay.

\section{Results}

\section{Antibacterial Spectrum}

The activity of BMY-28100, cefaclor and cephalexin against standard strains of bacteria stocked in our laboratory is shown in Table 1. BMY-28100 was about 2 to 4 times more active than cefaclor against 4 strains of Staphylococcus aureus, whereas the activity of cephalexin was inferior to that of cefaclor. Against most of the Gram-negative organisms tested, BMY-28100 was equivalent to cefaclor and about 4 to 8 times better than cephalexin. BMY-28100 showed good activity against Providencia rettgeri, it was 4 times as active as cefaclor. The strains of Morganella morganii and Enterobacter aerogenes were slightly susceptible to BMY-28100, but not to cefaclor and cephalexin. Enterobacter cloacae, Serratia marcescens and Pseudomonas aeruginosa were resistant to all of the cephalosporins tested. Table 2 shows the in vitro activities of these oral cephalosporins against 115 aerobic bacteria. BMY-28100 was most active against Gram-positive organisms among the cephalosporins tested. It was about 3 times as active as cefaclor against 19 strains of $S$. aureus and about 10 times more active than cefaclor against Streptococcus pyogenes and Streptococcus pneumoniae. Furthermore, BMY-28100 demonstrated an appreciable level of activity against Enterococcus faecalis which was resistant to cefaclor and cephalexin,

Table 1. Antibacterial spectrum of BMY-28100, cefaclor and cephalexin against standard strains of bacteria.

\begin{tabular}{|c|c|c|c|}
\hline \multirow{2}{*}{ Test organism } & \multicolumn{3}{|c|}{$\operatorname{MIC}(\mu \mathrm{g} / \mathrm{ml})$} \\
\hline & BMY -28100 & $\mathrm{CCL}$ & CEX \\
\hline Staphylococcus aureus FDA 209P JC-1 & 0.4 & 1.6 & 3.1 \\
\hline S. aureus Smith & 0.4 & 0.8 & 1.6 \\
\hline S. aureus Terajima & 0.1 & 0.4 & 0.2 \\
\hline S. aureus MS 353 & 0.2 & 0.8 & 1.6 \\
\hline Bacillus subtilis ATCC 6633 & 0.4 & 0.4 & 0.8 \\
\hline Escherichia coli NIHJ JC-2 & 1.6 & 1.6 & 6.3 \\
\hline E. coli $\mathrm{K}-12 \mathrm{C} 600$ & 1.6 & 1.6 & 6.3 \\
\hline Klebsiella pneumoniae PCI-602 & 0.4 & 0.4 & 3.1 \\
\hline Salmonella typhimurium IID 971 & 0.8 & 0.8 & 6.3 \\
\hline S. typhi 901 & 0.4 & 0.4 & 3.1 \\
\hline S. schottmuelleri 8006 & 0.8 & 0.8 & 3.1 \\
\hline S. enteritidis $\mathrm{G} 14$ & 0.4 & 0.4 & 1.6 \\
\hline Proteus mirabilis IFO 3849 & 1.6 & 1.6 & 12.5 \\
\hline P. vulgaris OX 19 & 25 & 25 & 25 \\
\hline P. vulgaris $\mathrm{HX} 19$ & 6.3 & 6.3 & 12.5 \\
\hline Providencia rettgeri IFO 3850 & 0.8 & 3.1 & 6.3 \\
\hline Morganella morganii IFO 3848 & 25 & 50 & $>100$ \\
\hline Enterobacter aerogenes ATCC 13048 & 25 & $>100$ & $>100$ \\
\hline E. cloacae 963 & 100 & $>100$ & $>100$ \\
\hline Serratia marcescens IAM 1184 & 100 & $>100$ & $>100$ \\
\hline Pseudomonas aeruginosa IFO 3445 & $>100$ & $>100$ & $>100$ \\
\hline$P$. aeruginosa $\mathrm{PAO} 1$ & $>100$ & $>100$ & $>100$ \\
\hline
\end{tabular}

CCL: Cefaclor, CEX: cephalexin. 
Table 2. In vitro antibacterial activity of BMY -28100 , cefaclor and cephalexin against aerobic bacteria.

\begin{tabular}{|c|c|c|c|}
\hline \multirow{2}{*}{$\begin{array}{l}\text { Test organism } \\
\text { (No. of strains) }\end{array}$} & \multirow{2}{*}{ Compound } & \multicolumn{2}{|c|}{$\operatorname{MIC}(\mu \mathrm{g} / \mathrm{ml})$} \\
\hline & & Range & Geometric mean \\
\hline Staphylococcus aureus (19) & $\begin{array}{l}\text { BMY }-28100 \\
\text { CCL } \\
\text { CEX }\end{array}$ & $\begin{array}{l}0.2 \sim 3.1 \\
0.2 \sim 12.5 \\
0.4 \sim 12.5\end{array}$ & $\begin{array}{l}0.74 \\
1.8 \\
2.4\end{array}$ \\
\hline Streptococcus pyogenes (6) & $\begin{array}{l}\text { BMY-28100 } \\
\text { CCL } \\
\text { CEX }\end{array}$ & $\begin{array}{l}0.05 \\
0.4 \\
0.8\end{array}$ & $\begin{array}{l}0.05 \\
0.40 \\
0.80\end{array}$ \\
\hline S. pneumoniae (6) & $\begin{array}{l}\text { BMY }-28100 \\
\text { CCL } \\
\text { CEX }\end{array}$ & $\begin{array}{l}0.05 \sim 0.2 \\
0.4 \sim 3.1 \\
0.8 \sim 3.1\end{array}$ & $\begin{array}{l}0.11 \\
1.6 \\
1.8\end{array}$ \\
\hline Enterococcus faecalis (15) & $\begin{array}{l}\text { BMY }-28100 \\
\text { CCL } \\
\text { CEX }\end{array}$ & $\begin{array}{l}0.8 \sim 25 \\
6.3 \sim>100 \\
6.3 \sim>100\end{array}$ & $\begin{array}{r}9.9 \\
>100 \\
87\end{array}$ \\
\hline E. faecium (5) & $\begin{array}{l}\text { BMY-28100 } \\
\text { CCL } \\
\text { CEX }\end{array}$ & $\begin{aligned} & 25 \\
& 100 \sim>100 \\
> & 100\end{aligned}$ & $\begin{array}{r}25 \\
>100 \\
>100\end{array}$ \\
\hline Haemophilus influenzae (10) & $\begin{array}{l}\text { BMY-28100 } \\
\text { CCL } \\
\text { CEX }\end{array}$ & $\begin{array}{c}0.4 \sim 0.8 \\
0.8 \sim 1.6 \\
3.1\end{array}$ & $\begin{array}{l}0.65 \\
0.98 \\
3.1\end{array}$ \\
\hline Neisseria gonorrhoeae (8) & $\begin{array}{l}\text { BMY-28100 } \\
\text { CCL } \\
\text { CEX }\end{array}$ & $\begin{array}{l}0.013 \sim 6.3 \\
0.05 \sim 25 \\
0.05 \sim 12.5\end{array}$ & $\begin{array}{l}0.68 \\
1.0 \\
1.4\end{array}$ \\
\hline N. meningitidis (5) & $\begin{array}{l}\text { BMY }-28100 \\
\text { CCL } \\
\text { CEX }\end{array}$ & $\begin{array}{l}0.4 \\
0.8 \\
0.8\end{array}$ & $\begin{array}{l}0.40 \\
0.80 \\
0.80\end{array}$ \\
\hline Escherichia coli (13) & $\begin{array}{l}\text { BMY-28100 } \\
\text { CCL } \\
\text { CEX }\end{array}$ & $\begin{array}{l}0.8 \sim 25 \\
0.8 \sim 100 \\
3.1 \sim 50\end{array}$ & $\begin{array}{l}4.1 \\
6.3 \\
11\end{array}$ \\
\hline Klebsiella pneumoniae (11) & $\begin{array}{l}\text { BMY-28100 } \\
\text { CCL } \\
\text { CEX }\end{array}$ & $\begin{array}{l}0.8 \sim 100 \\
0.8 \sim 100 \\
1.6 \sim 100\end{array}$ & $\begin{array}{l}3.0 \\
2.5 \\
6.3\end{array}$ \\
\hline Proteus mirabilis (10) & $\begin{array}{l}\text { BMY-28100 } \\
\text { CCL } \\
\text { CEX }\end{array}$ & $\begin{aligned} 0.8 & \sim 1.6 \\
1.6 & \sim 3.1 \\
12.5 & \sim 25\end{aligned}$ & $\begin{array}{l}1.3 \\
2.0 \\
15\end{array}$ \\
\hline
\end{tabular}

CCL: Cefaclor, CEX: cephalexin.

although the strains of Enterococcus faecium were resistant to these three cephalosporins. Against Haemophilus influenzae and Neisseria gonorrhoeae, the activities of BMY-28100 were slightly superior to those of cefaclor and cephalexin. BMY-28100 was twice as active as cefaclor and cephalexin against Neisseria meningitidis and comparable to cefaclor against Escherichia coli. The strains of Klebsiella pneumoniae were also similarly susceptible to BMY-28100 and cefaclor, but cephalexin was 4 times weaker than BMY-28100. The activity of BMY-28100 against Proteus mirabilis was somewhat better than that of cefaclor and about 10 times superior to cephalexin.

\section{Bactericidal Activity}

The bactericidal activity of BMY-28100 was compared with that of cefaclor and cephalexin against three test organisms (Fig. 2). The MIC value of BMY-28100 against S. aureus Smith was $0.8 \mu \mathrm{g} / \mathrm{ml}$ 
Fig. 2. Bactericidal activity of BMY-28100, cefaclor and cephalexin in Mueller-Hinton broth. CCL: Cefaclor, CEX: cephalexin. Staphylococcus aureus smith

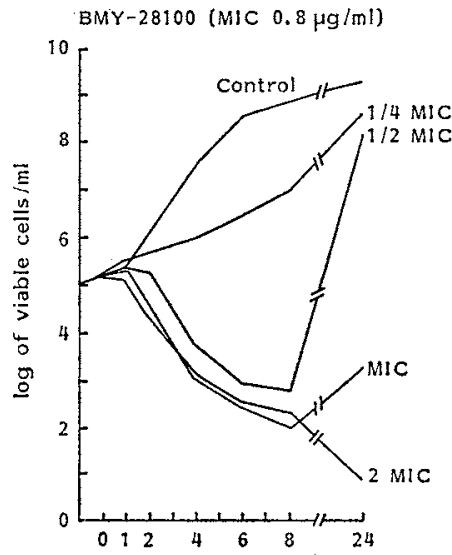

Escherichia coli Juht

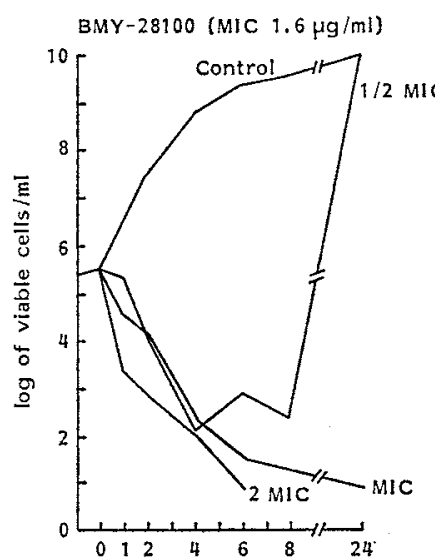

Proteus mirabilis A 9900

BMY-28100 (MIC $0.8 \mu \mathrm{g} / \mathrm{ml})$

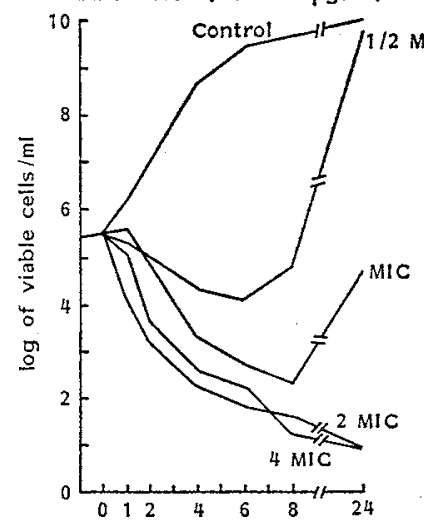

$\mathrm{CCL}(\mathrm{MIC} 1.6 \mu \mathrm{g} / \mathrm{ml})$

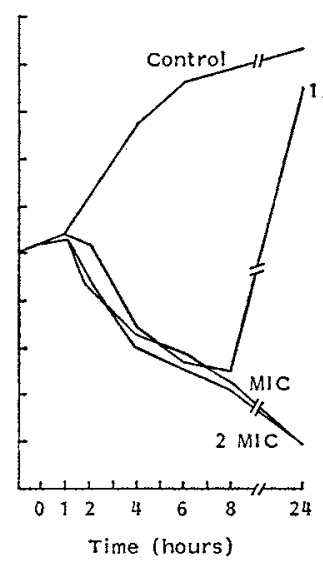

$\mathrm{CCL}(\mathrm{MlC} 0.8 \mu \mathrm{g} / \mathrm{ml})$

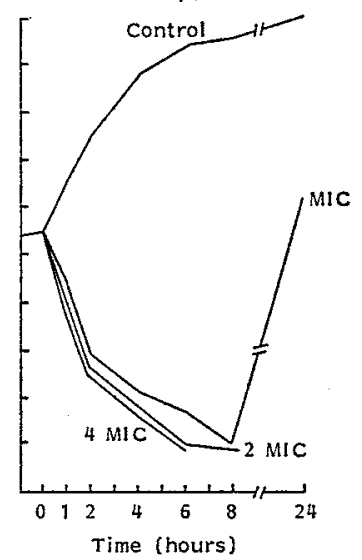

$\mathrm{CCL}(\mathrm{MIC} 0.8 \mu \mathrm{g} / \mathrm{mI})$

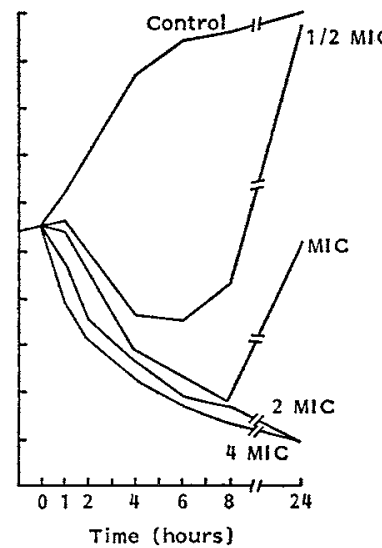

$\operatorname{CEX}(M / C 6.3 \mu \mathrm{g} / \mathrm{ml})$

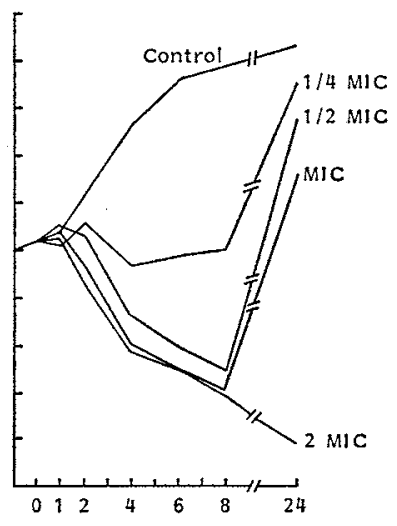

CEX (M/C $6.3 \mu \mathrm{g} / \mathrm{ml}$ )

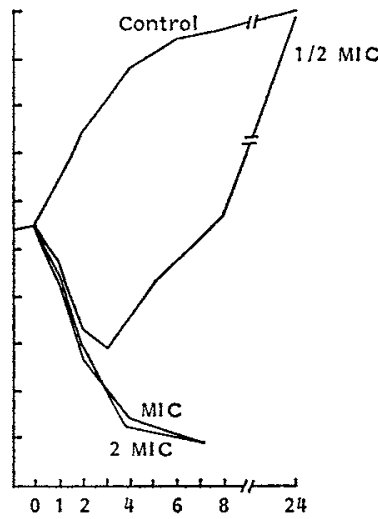

CEX (MIC $25 \mu \mathrm{g} / \mathrm{m})$ )

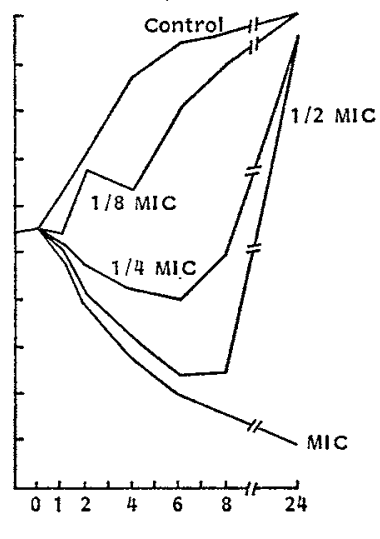


Table 3. Relative stability of BMY-28100, cefaclor and cephalexin against $\beta$-lactamases.

\begin{tabular}{|c|c|c|c|c|c|}
\hline \multirow{2}{*}{ Enzyme source } & \multicolumn{5}{|c|}{$\operatorname{RHR}(\%)$} \\
\hline & PCG & CER & BMY -28100 & $\mathrm{CCL}$ & CEX \\
\hline \multicolumn{6}{|l|}{ Penicillinase: } \\
\hline Escherichia coli W3630/Rms 212 & 100 & 34 & 4 & 5 & $<1$ \\
\hline E. coli ML1410 RGN 14 & 100 & 14 & 5 & $<1$ & $<1$ \\
\hline E. coli ML1410 RGN 823 & 100 & 32 & 8 & 6 & $<1$ \\
\hline Pseudomonas aeruginosa Ml/Rms139 & 100 & $<1$ & $<1$ & $<1$ & $<1$ \\
\hline \multicolumn{6}{|l|}{ Cephalosporinase: } \\
\hline Enterobacter cloacae GN7471 & & 100 & 20 & 96 & 28 \\
\hline Citrobacter freundii GN7391 & & 100 & 19 & 86 & 33 \\
\hline \multicolumn{6}{|l|}{ Cefuroxime-hydrolyzing $\beta$-lactamase: } \\
\hline Proteus vulgaris GN7919 & & 100 & 82 & 264 & 21 \\
\hline Bacteroides fragilis 308 & & 100 & 16 & 76 & 4 \\
\hline
\end{tabular}

RHR: Relative hydrolysis rate by $\beta$-lactamases. PCG: Benzylpenicillin, CER: cephaloridine, CCL: cefaclor, CEX: cephalexin.

Table 4. Protective effect of BMY-28100, cefaclor and cephalexin against experimental infections in mice.

\begin{tabular}{lccc}
\hline \multicolumn{1}{c}{ Test organism } & \multicolumn{3}{c}{ PD $_{50}(\mathrm{mg} / \mathrm{kg}, \mathrm{po})$} \\
\cline { 2 - 4 } & $\mathrm{BMY}-28100$ & $\mathrm{CCL}$ & CEX \\
\hline Staphylococcus aureus Smith & 0.09 & 0.17 & 0.42 \\
S. aureus BX-1633 & 1.3 & 2.2 & 17 \\
Streptococcus pyogenes A20201 & 0.07 & 0.14 & 0.74 \\
Haemophilus influenzae A9729 & 1.1 & 1.6 & 18 \\
Escherichia coli Juhl & 1.1 & 0.8 & 1.0 \\
Proteus mirabilis A9554 & 1.1 & 1.8 & 13 \\
\hline
\end{tabular}

CCL: Cefaclor, CEX: cephalexin.

and its $\mathrm{MBC}$, the $\mathrm{MBC}$, was $1.6 \mu \mathrm{g} / \mathrm{ml}$, whereas the $\mathrm{MIC}$ value of cefaclor, $1.6 \mu \mathrm{g} / \mathrm{ml}$ corresponded to its MBC. Against both Gram-negative bacteria, the bactericidal activity of BMY-28100 was same as that of cefaclor and 2- to 16 -fold better than that of cephalexin.

Stability to $\beta$-Lactamases

The $\beta$-lactamase stability of BMY-28100 was assayed by determining relative rates of hydrolysis by various $\beta$-lactamases (Table 3). BMY-28100, cefaclor and cephalexin were resistant to hydrolysis by 4 types of penicillinases. BMY-28100 and cephalexin were moderately hydrolyzed by cephalosporinases from E. cloacae and Citrobacter freundii, whereas the hydrolysis rate of cefaclor was nearly equivalent to that of cephaloridine. Against cefuroxime-hydrolyzing $\beta$-lactamases of Proteus vulgaris and Bacteroides fragilis, cephalexin was most resistant among the cephalosporins tested, and cefaclor was most sensitive to Richmond type $\mathrm{C}$ cefuroxime-hydrolyzing $\beta$-lactamase ${ }^{8}$.

\section{Protective Activity}

Table 4 shows the in vivo therapeutic acivities of BMY-28100 administered orally to the mice infected with a variety of bacteria compared with those of cefaclor and cephalexin. BMY-28100 showed the best activity against three Gram-positive bacterial infections, it was about twice as active as cefaclor and 5- to 10-fold superior to cephalexin. Against Gram-negative organisms, BMY-28100 was equal to or slightly better than cefaclor, whereas cephalexin was 7 to 16 times inferior to BMY-28100. 
Table 5. Pharmacokinetic parameters of BMY-28100, cefaclor and cephalexin after oral administration to mice and rats.

\begin{tabular}{|c|c|c|c|c|c|}
\hline \multirow[b]{2}{*}{ Compound } & \multirow{2}{*}{$\begin{array}{c}\text { Dose } \\
(\mathrm{mg} / \mathrm{kg}, \text { po })\end{array}$} & \multicolumn{3}{|c|}{ Blood level parameters ${ }^{a}$} & \multirow{2}{*}{$\begin{array}{l}\text { Recovery } \\
\text { in urine } \\
(\%)\end{array}$} \\
\hline & & $\underset{(\mu \mathrm{g} / \mathrm{ml})}{\mathrm{Cmax}}$ & $\begin{array}{c}\mathrm{T}_{1 / 2} \\
\text { (hours) }\end{array}$ & $\begin{array}{c}\text { AUC } \\
(\mu \mathrm{g} \cdot \text { hours } / \mathrm{ml})\end{array}$ & \\
\hline \multicolumn{6}{|l|}{ Mice $(n=10)$} \\
\hline BMY-28100 & 50 & $27 \pm 1.3$ & $0.83+0.06$ & $34 \pm 2.0$ & 73 \\
\hline CCL & 50 & $28 \pm 1.7$ & $0.60 \pm 0.04$ & $22 \pm 1.9$ & 60 \\
\hline CEX & 50 & $27 \pm 2.1$ & $0.58 \pm 0.04$ & $26 \pm 1.4$ & 75 \\
\hline \multicolumn{6}{|l|}{ Rats $(n=5)$} \\
\hline \multirow[t]{2}{*}{ BMY-28100 } & 80 & $15 \pm 2.0$ & $2.1 \pm 0.20$ & $65 \pm 2.3$ & 46 \\
\hline & 40 & $14 \pm 1.3$ & $1.9 \pm 0.18$ & $41 \pm 1.6$ & 46 \\
\hline \multirow[t]{2}{*}{$\mathrm{CCL}$} & 80 & $16 \pm 1.0$ & $2.0 \pm 0.15$ & $43 \pm 2.4$ & 39 \\
\hline & 40 & $7.5 \pm 0.57$ & $2.0 \pm 0.11$ & $21 \pm 0.60$ & 38 \\
\hline \multirow[t]{2}{*}{ CEX } & 80 & $17 \pm 1.1$ & $2.7 \pm 0.08$ & $63 \pm 5.3$ & 57 \\
\hline & 40 & $12 \pm 1.6$ & $2.5 \pm 0.73$ & $47 \pm 3.7$ & 52 \\
\hline
\end{tabular}

Data represents the mean $\mathrm{SE}$.

a Blood collection (time after drug administration), mice: $0.25,0.5,0.75,1,1.5,2,2.5$ and 3 hours, rats: $0.5,1,2,3,4,5,6$ and 7 hours.

b 0 to 24 hours collection period.

CCL: Cefaclor, CEX: cephalexin.

Fig. 3. Stability of BMY-28100, cefaclor and cephalexin in serum at $37^{\circ} \mathrm{C}$. CCL: Cefaclor, CEX: cephalexin.

Human serum ( $\mathrm{pH} 6.8)$

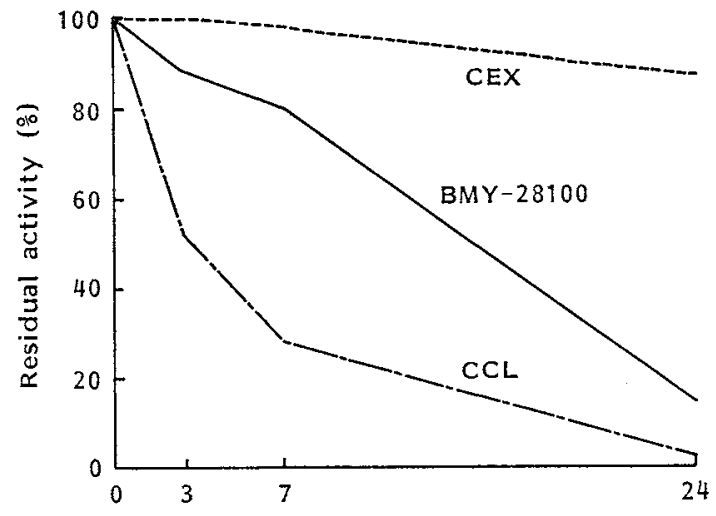

Calf serum $(\mathrm{pH} 7.6)$

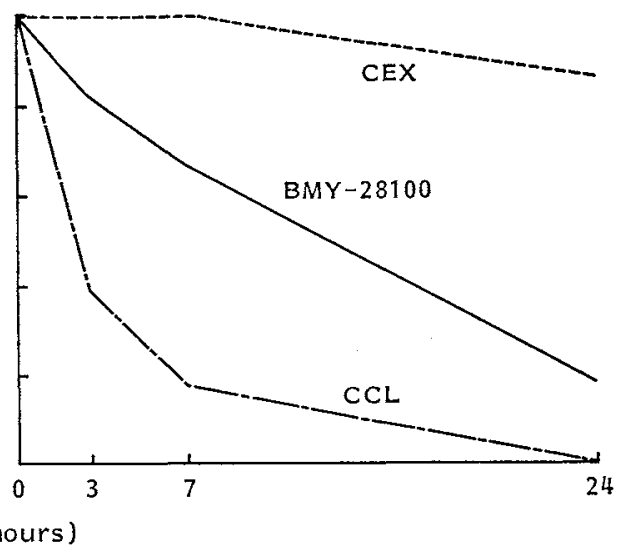

Blood Level and Urinary Recovery

The blood level and urinary excretion of BMY-28100 were examined in mice and rats after oral administration and the results are shown in Table 5. The half-life value of BMY-28100 in mice was longer than those of cefaclor and cephalexin and its AUC value was also significantly greater than that of cefaclor. The AUC values of BMY-28100 were also greater than those of cefaclor and comparable to those of cephalexin in rats. The urinary recovery rates of BMY-28100 were slightly higher than those of cefaclor in both mice and rats.

\section{Stability in the Serum}

As shown in Fig. 3, BMY-28100 was significantly more stable to cefaclor in both human and calf sera, though cephalexin was the most stable among the cephalosporins tested. 


\section{Discussion}

BMY-28100 was compared with cefaclor and cephalexin in the in vitro and in vivo antibacterial activities and bioavailability in mice and rats. The compound showed better in vitro activity than cefaclor and cephalexin which was currently available for clinical use. Especially, against Gram-positive organisms, such as $S$. aureus, S. pyogenes, S. pneumoniae and E. faecalis, BMY-28100 was 3 to 20 times more active than cefaclor and cephalexin. Against Gram-negative organisms, BMY-28100 had slightly better or comparable activity to cefaclor, which has been reported to have more potent activity than cephalexin, cephaloglycin and cephradine against Gram-negative bacteria ${ }^{9,10)}$. The bactericidal activity of BMY-28100 was almost equivalent to that of cefaclor, its $\mathrm{MBC}$ values were equal to or twice as high as MIC values. The stability of cefaclor to various types of $\beta$-lactamases has been reported by NeU and $\mathrm{FU}^{\mathrm{i1}}$. In our experiments, BMY-28100 was slightly more stable than cefaclor against cephalosporinase and cefuroxime-hydrolyzing $\beta$-lactamase. The in vivo therapeutic efficacy of BMY-28100 was well correlated to its in vitro activity, and was better than that of cefaclor against five out of six Gram-positive and Gram-negative bacterial infections. The pharmacokinetic profiles of cefaclor in laboratory animals and human volunteers ${ }^{12,13)}$ have been reported. BMY-28100 showed blood level parameters superior to those of cefaclor and comparable to those of cephalexin in rodent animals. The stability in the serum of oral cephalosporins was also examined, since the instability of cefaclor in the serum and buffer solution was reported by FOGLESONG et al. ${ }^{14)}$. BMY-28100 was significantly more stable than cefaclor in both human and calf sera.

\section{Acknowledgments}

The authors wish to thank Drs. T. OKI and T. NaITo of this Institute for valuable discussions throughout the present study and Dr. R. E. KessLer of Bristol-Myers Company for the review of this article. The excellent technical assistance of T. Hoshrya, T. ANdo, H. Fujimura, M. Yamanaka, U. SAto and Y. Asai is gratefully acknowledged. We also thank H. Hoshi, Y. ABE, S. Aburaki and J. Okumura for the preparation and supply of BMY-28100.

\section{References}

1) Naito, T.; H. Hoshi, S. Aburaki, Y. Abe, J. Okumura, K. Tomatsu \& H. Kawaguchi: Synthesis and structure-activity relationships of a new oral cephalosporin, BMY-28100 and related compounds. J. Antibiotics 40: $991 \sim 1005,1987$

2) Tomatsu, K.; T. Hosmya, S. ANdo \& T. MrYaki: Preliminary laboratory evaluation of BMY-28100. Abstracts of Papers of 14th Int. Congr. Chemother., S-14-9, p. 124, Kyoto, June 23 28, 1985

3) Leitner, F.; M. Misiek, T. A. Pursiano, R. E. Buck, D. R. Chisholm, R. G. DeRegis, Y. H. Tsai \& K. E. PRICE: Laboratory evaluation of BL-S786, a cephalosporin with broad-spectrum antibacterial activity. Antimicrob. Agents Chemother. 10: 426 435, 1976

4) Mitsuhashi, S. \& M. Inoue: Mechanisms of resistance to $\beta$-lactam antibiotics. In Beta-lactam Antibiotics. Ed., S. Mitsuhashi, pp. $41 \sim 56$, Springer-Verlag New York, Inc., New York, 1981

5) Ross, G. W.; K. V. Chanter, A. H. Harris, S. M. Kirby, M. J. Marshall \& C. H. O'Callaghan: Comparison of assay technique for $\beta$-lactamase activity. Anal. Chem. 54:9 16, 1973

6) SAmuni, A.: A direct spectrophotometric assay and determination of Michaelis constants for the $\beta$ lactamase reaction. Anal. Biochem. 63:17 26, 1975

7) LitChfield, J. T. \& F. Wilcoxon: Simplified method of evaluating dose effect experiments. J. Pharmacol. Exp. Ther. 96: 99 113, 1949

8) Hirai, K.; S. IYobe, M. Inoue \& S. Mirsuhashi: Purification and properties of a new $\beta$-lactamase from Pseudomonas cepacia. Antimicrob. Agents Chemother. 17:355 358, 1980

9) BILL, N. J. \& J. A. WASHINGTON II: Comparison of in vitro activity of cephalexin, cephradine, and cefaclor. Antimicrob. Agents Chemother. 11: 470 474, 1977

10) Shadomy, S.; G. Wagner \& M. Carver: In vitro activities of five oral cephalosporins against aerobic pathogenic bacteria. Antimicrob. Agents Chemother. 12: 609 613, 1977

11) NeU, H. C. \& K. P. Fu: Cefaclor: In vitro spectrum of activity and beta-lactamase stability. Antimicrob. Agents Chemother. 13: 584 588, 1978 
12) KorzeniowsKi, O. M.; W. M. SCheld \& M. A. SANDE: Comparative pharmacology of cefaclor and cephalexin. Antimicrob. Agents Chemother. 12: 157 162, 1977

13) Sullivan, H. R.; S. L. Due, D. L. K. Kau, J. F. Quay \& W. M. Miller: Metabolism of $\left[{ }^{14} \mathrm{C}\right]$ cefaclor, a cephalosporin antibiotic, in three species of laboratory animals. Antimicrob. Agents Chemother. 10: $630 \sim 638,1976$

14) Foglesong, M. A.; J. W. Lamb \& J. V. Dietz: Stability and blood level determinations of cefaclor, a new oral cephalosporin antibiotic. Antimicrob. Agents Chemother. 13: 49 52, 1978 